\title{
ЭСТЕТИКА
}

\section{В.В. Дубовицкий}

\section{ИСКУССТВО, КРАСОТА \\ И БЛАГО В ЭСТЕТИКЕ ПЛАТОНА}

Аннотация. Рассуждения Платона о красоте, об искусстве нередко подвергались критике, в особенности начиная со времени, когда эстетическая срера стала пониматься как сугубо автономная (поверхностная интерпретация этой концепции автономии не позволяла продумать феномены искусства и красоты в перспективе блага), а вопрос о полезности искусства, который Платон ставил со всей остротой философских вопросов, переместился в сферу социал-демократической идеологии и общественной мысли, приобрёл публицистический характер. В данной статье эстетика Платона рассматривается в горизонте идеи блага. Предпринимается попытка провести параллели между критическими рассуждениями Платона об искусстве и рядом идей, высказанных такими мыслителями, как И. Винкельман, Ж.-Ж. Руссо, Ф. Ницие, 3. Фрейд. Так, речь может идти о преодолении привычки говорить об искусстве в целом исключительно в позитивном смысле, о протесте против эстетизации страстей как социально вредного феномена и т.д. В контексте рефлексий о красоте и об искусстве выявляется возможность сопоставления на первый взгляд чуждых друг другу феноменов - «естественного» человека Руссо с гражданином идеального государства Платона. В статье показывается также, каким образом в перспективе идеи блага разрабатывает Платон тему чистых удовольствий - тему, имеющую своё продолжение в таких направлениях постклассического искусства, как абстракционизм и минимализм. В контексте идеи блага акцентируется также связь эротической философии Платона со сферой теологии.

В данной статье были использованы некоторые принципы онтологического исследования, герменевтики, а также - сравнительного и феноменологического методов.

В данном исследовании выявляется позитивный смысл критики Платоном расхожего «пещерного» воззрения на красоту и искусство и акцентируется бытийное измерение этих феноменов в философской эстетике Платона. Все аналогии и параллели, приведённые в исследовании, не случайны. Они позволяют выявить и по сей день актуальное содержание платоновской эстетики, которая, как и вся философия Платона, есть поиск блага, его оснований в человеческом бытии.

Ключевые слова: благо, эстетика, онтология, искусство, красота, страсти, подражание, польза, удовольствие, эротический опыт.

Abstract. The reasoning of Plato on beauty, art is often criticized, especially from the time when the aesthetic sphere began to be understood as a purely autonomous (superficial interpretation of the concept of autonomy is not allowed to consider the phenomena of art and beauty in the long term benefits), and the usefulness of art, which Plato put acutely philosophical issues, has moved into the sphere of social-democratic ideology and social thought, has acquired a journalistic character. In this article the aesthetics of Plato is seen in the horizon of good ideas. Attempts to draw parallels between the critical reasoning of Plato on art and a number of ideas of such thinkers as J. Winkelmann, J. J. Rousseau, F. Nietzsche, S. Freud. So, we can talk about overcoming the habit of talking about art in general only in the positive sense, about the protest against the aesthetics of the passion as a socially harmful phenomenon, etc. In the context of reflections about the beauty and art reveals the comparison at first glance alien to each other phenomena-the "natural" man Rousseau, a citizen of the ideal state of Plato. The paper shows also how in the future the idea of the good of Plato develops the theme of pure pleasure - a theme that has continued in the areas of post-classical art, abstractionism and minimalism. In the context of the good ideas also emphasized the erotic relationship of the philosophy of Plato with the sphere of theology. In this article, we have used some of the principles of ontological studies, hermeneutics, and comparative and phenomenological methods. This study revealed a positive sense of criticism of Plato common "cave" views on art and beauty and is accented existential dimension of these phenomena in the philosophical aesthetics of Plato. All analogies and parallels given in the study, not random. They allow to identify a still relevant content of Plato's aesthetics, which as the entire Plato's philosophy, is a search of good, and its foundations within the human being.

Key words: fun, use, imitation, passion, beauty, art, ontology, aesthetics, good, erotic experience. 
«...благо не имеет нужды в красоте, а красота нуждается в благе. Благу свойственна мягкость, нежность, ласковость, и кто как хочет, так и наслаждается им, а красота вызывает изумление, как бы поражает, и даёт наслаждение не без некоторой доли страдания, а что хуже всего, нередко отдаляет от добра людей нерассудительных и неосторожных. Благо старше красоты не по времени, а по своему более истинному и реальному существу, по своей большей мощи и власти» [1, с. 183].

Многие эстетические проблемы, которые Платон с той или иной степенью подробности обсуждал в своих диалогах, оказывались в центре философских, эстетических, идеологических дискуссий в различные периоды истории западной культуры. Платон унаследовал философские и эстетические идеи и интуиции пифагорейцев, но сделал решительный шаг в осмыслении красоты как абстрактного универсального начала, тщательно отделяя красоту как идею от всех проявлений её эмпирического существования. Однако же сам феномен красоты Платон рассматривает в его многообразной специфике, выявляя функцию красоты в отношении блага. Онтологический смысл красоты в платоновской эстетике заключается в том, что правильное её восприятие, правильное «пользование» ею позволяет раскрыть фундаментальные структуры человеческого бытия в его высочайших возможностях.

\section{Искусство, теология и политика}

Учитывая значительную политическую опосредованность всей философии Платона, следует отметить, что тема соотношения искусства и политики является особо значимой в платоновской эстетике. Мнения, высказываемые Платоном по данной теме, нередко воспринимались как нечто одиозное. Однако следует учитывать, что Платон, будучи, несомненно, религиозным и политическим мыслителем, отчётливо видел в искусстве те негативные моменты, которые, очевидно, не только в те далёкие времена, но и в наше время не принято обсуждать в среде «эстетически» экзальтированных «любителей» искусства. Можно было бы резюмировать основные критические аргументы Платона в адрес искусства следующим образом: искусство, по сути, всего лишь подражает существующим в мире формам, отношениям; произведения искусства - лишь видимости, они менее ценны, чем то, что реально существует в мире, находится в потоке становления и приносит реальную пользу, т.е. изделия, а также продукты педагогической, политической и иной деятельности; искусство способно возбуждать, культивировать низшие сферы психики, страсти легко воспроизводятся, заразительны, имеют успех у толпы, а для этого привлекается весь арсенал искусства.

Было бы ошибкой, если с «высоты» современной культуры однозначно предосудительно относиться к политическим и педагогическим идеям Платона, касающимся также и сферы искусства, какими бы «чуждыми» они нам сейчас ни казались. Иначе познающий разум окажется вне герменевтической культуры (которая ведь требует понимания, но не обязательно принятия), а, значит - вне возможности продуктивного понимания. Искусство Платон рассматривает не как нечто самодостаточное, не как сферу досужего любования эстетическими и иными смыслами бытия, а как средство гармоничного устроения общества и человека. Ведь для человека как такового, а также как гражданина, необходима уравновешенность души, что позволяет обратить его взор к реальности и отвратить от видимости. Но именно этому и препятствует, с точки зрения Платона, искусство с его чарами: «Будь то любовные утехи, гнев или всевозможные другие влечения нашей души - её печали и наслаждения... всё это возбуждается в нас поэтическим воображением. Оно питает всё это, орошает то, чему надлежало бы засохнуть, и устанавливает его власть над нами...» [2, с. 404].

Каковы же аргументы Платона, который, как известно, сам в молодости пробовал себя в поэтическом творчестве? Один из главных аргументов состоит в том, что мифопоэтическое творчество искажает представления человека о божественной сфере. И здесь Платон далеко не одинок: например, ещё элеат Ксенофан считал нечестием утверждение о том, что боги родились или умерли, рассказы о воровстве, прелюбодеянии и т.п. среди богов. Когда поэтически воспеваются сражения титанов, гигантов, кентавров, - всё это, принимаемое за чистую монету, формирует множество иллюзий в представлениях людей о божественном. Даже, говорит Платон, если бы дела Кроноса и низвержение его в Тартар Зевсом, его сыном - если бы всё это и было правдой, всё равно не следует рассказывать об этом тем, кто ещё молод и неразумен, это могут выслушать лишь немногие и втайне. Здесь Платон явно намекает на мистериальный смысл некоторых мифов, а именно тех, которые использовались в мистериях, в которые, как известно, посвящались немногие и втайне. Платон выступает здесь как подлинный философ, понимая, что в представлениях людей о богах есть много иллюзорного, ис- 


\section{Философия и культура 4(100) • 2016}

кусственного, чрезмерно художественного, что мешает пониманию религиозных истин. В этой связи небезынтересно привести суждение Ф. Шеллинга, который, анализируя с философской точки зрения мифологический процесс в языческой античности, указывал на важнейший смысл элевсинских таинств, посвящённых Дионису и Деметре, - смысл, открывающий глубинные пласты религиозно-мифологического сознания античности: «Сознание уже видело, как старый мир богов, додионисийский, мир титанов, нисходил во тьму Тартара; как вероятно, что и этот дионисийский мир богов исчезал одновременно с богом (Имеется в виду Дионис второй потенции - Дионис-Вакх (Бахус). (Прим. моё. - В.Д.)), который сам не был последним и как властитель настоящего... сам имел будущее вне себя! Данное учение о будущем третьем властителе мира (О Дионисе третьей потенции - ДионисеИакхе. (Прим. моё. - В.Д.)) и грядущей вместе с ним духовной религии, которая только и освободит сознание полностью от результата мифологического процесса, лишь уживалось... с системой публичной веры в богов...» [3, с. 606]. Аргументы Платона против неумеренной поэтизации сферы теологии имеют своё рациональное основание также и в педагогическом смысле. Так, рассуждая о воспитании детей, Платон говорит: «Ребёнок не в состоянии судить, где содержится иносказание, а где нет, и мнения, воспринятые им в таком раннем возрасте, обычно становятся неизгладимыми и неизменными. Вот почему, пожалуй, более всего надо добиваться, чтобы первые мифы, услышанные детьми, самым заботливым образом были направлены к добродетели» [2, с. 142].

Платон столь настойчиво предупреждает о недопустимости претензий искусства на правдоподобие в изображении божественных сфер не только по политическим мотивам, но и в силу своих метафизических воззрений: нечто невыразимое не должно передаваться, не может быть передано средствами искусства, как правило, всегда тяготеющего к общедоступным, антропоморфным образам - невыразимое может быть доступно только духовному созерцанию вследствие определённой (философской, мистической) практики. 0 невыразимом как не поддающемся никакому означиванию Платон весьма категорично говорит в своём Седьмом письме: «У меня самого по этим вопросам нет никакой записи и никогда не будет. Это не может быть выражено в словах, как остальные науки; только если кто постоянно занимается этим делом и слил с ним всю свою жизнь, у него внезапно, как свет, засиявший от искры огня, возникает в душе это сознание и само себя там питает» [4, с. 493].
Искусство может способствовать возбуждению вполне реальных страстей, а уж если и боги изображаются испытывающими похоть, соблазняя друг друга, то подобные картины, соединённые с горячительно-разнузданной «неземной» фантазией, вполне могут возбудить - по принципу подражания - те же самые страсти, но только ещё более усиленные фантазмом. В этом смысле весьма показателен эпизод из Гомера, пересказанный Платоном: Зевс, «когда все остальные боги и люди спали и только один он бодрствовал, то из-за страстного любовного вожделения он просто позабыл обо всём, что замыслил (Помощь троянцам. (Прим. моё. - В.Д.)) и при виде Геры настолько был поражён страстью, что не пожелал даже взойти в опочивальню, но решился тут же, на земле, соединиться с ней, признаваясь, что страсть охватила его с такой силой, как никогда не бывало даже при первой их встрече...» [2, с. 154]. Платон считает недопустимым, чтобы такая «...страсть обхватила могучую душу» [5, с. 228].

А. Лосев в своём анализе социальной природы платонизма резюмирует платоновский ответ на вопрос «Чем является вся греческая мифология?» следующим образом: «Знание должно быть идеальным, тем более о богах. Питаться все граждане, а в особенности воспитанники, должны идеальным знанием. Боги как раз суть эти идеальные сущности, неизменные и вечные, и они могут быть даны только в адекватно выраженных, вечно-неизменных мифах» [6, с. 829]. Однако, и об этом пишет Лосев, Платон в своей критике греческой мифологии вовсе не отрицал эту самую мифологию, а стремился, так сказать, упорядочить её использование в сугубо социальных, воспитательных целях, в частности, в поэтическом творчестве. Лосев, интерпретируя Платона, отрицает простое морализаторство как доминанту критики Платоном мифологии, а в качестве такой доминанты указывает на несомненно содержащиеся в теологии Платона догматические тенденции. Лосев пишет: «Догматическое богословие - вот она, единственная мифология, которую признаёт Платон... Ему-то и хочет учить Платон стражей своего народа. Никакая другая мифология, никакие рассказы, мифы, учения, никакое другое знание о богах не есть нечто достойное, истинное и нужное» [6, с. 833]. Именно в этом специфическом контексте, очевидно, и следует рассматривать платоновскую ревизию и цензуру мифологии, в том числе применительно к сфере искусства.

Платон видит вред в искусстве, возбуждающем у человека страх. Как бы мы сейчас сказали, Платон - против эстетизации страха. Здесь, если 
попытаться понять Платона, можно было бы сослаться на психологический механизм возбуждения страстей как бы по цепной реакции, а также на то, что чувства, испытываемые неискушённым в тонкостях эстетического опыта человеком, во время восприятия им произведения искусства могут быть и не такими уж «театральными», «художественными» - страхи, вожделения и другие аффекты, вызываемые чарами искусства, могут оказать и вполне реальное воздействие на душу и разум такого неискушённого в искусстве человека, делая его неестественно чувствительным. Всё это, очевидно, имеет в виду Платон в следующем знаменитом пассаже: «Мы извиняемся перед Гомером и остальными поэтами - пусть они не сердятся, если мы вычеркнем эти и подобные им стихи, и не потому, что они непоэтичны и неприятны большинству слушателей, нет, наоборот: чем более они поэтичны, тем менее следует их слушать и детям и взрослым, раз человеку надо быть свободным и больше смерти страшиться рабства... кроме того, следует отбросить и все связанные с этим страшные, пугающие обозначения - «Кокит», «Стикс», «покойники», «усопшие» и так далее, отчего у всех слушателей волосы встают дыбом. Возможно, что всё это пригодно для какой-нибудь другой цели, но мы опасаемся за наших стражей, как бы они не сделались у нас от таких потрясений чересчур возбудимыми и чувствительными» [2, с. 150]. Не эстетический аспект искусства как таковой интересует здесь Платона, а связанное с воздействием искусства состояние души членов идеального полиса. Действительно, вряд ли можно оспорить поэтичность песней «Одиссеи», соединённую с визионерской глубиной её образов, да это признаёт и сам Платон. Однако он стремится освободить искусство не только от «излишней» сентиментальности и аффективности, но и предотвратить такое возможное прямое воздействие искусства на человека, когда изображенные страсти способствуют возбуждению страстей вполне реальных, а если быть точнее - когда страсти, испытываемые человеком по поводу изображенных страстей, подменяют, вытесняют, если выразиться в духе Ж.-Ж. Руссо, естественного человека, замыкая аффекты, чувственность в круге «эстетических» переживаний (с изрядной долей нарциссизма), не раскрывающих ни действительного человека, ни его мира.

У Платона вырисовывается некий идеальный (богоподобный) образ человека, жизнь такого человека отличается самодовлением и бесстрашием, и ему совершенно ни к чему эти искусственные, театральные страхи, страсти, переживания героев.
Возможно, размышления Ф. Ницше помогут нам здесь лучше понять Платона, ведь Ницше тоже стремился увидеть образ некоего идеального человека, свободного от страхов, сентиментальностей, аффектации. Именно в произведениях Р. Вагнера, в этих, по мнению Ницше, чересчур театрализованных действах, было нечто, что, как полагал философ, расшатывало психическое здоровье человека, уводило его душу от духовных созерцаний в сторону аффектов, неврозов, которыми можно ещё и наслаждаться, - словом, погружало человека в мир причудливых созданий его воображения, подпитываемого рассчитанными на эффекты, массовость, как полагал Ницше, постановками творений Вагнера. Ницше писал о негативных, с его точки зрения, сторонах творчества Вагнера: «Проблемы, выносимые им на сцену, - сплошь проблемы истеричных, - конвульсивное в его аффектах, его чрезмерно раздражённая чувствительность, его вкус, требующий всё более острых приправ, его непостоянство, переряжаемое им в принципы, не в малой степени выбор его героев и героинь, если посмотреть на них как на физиологические типы (- галерея больных! -): всё это вместе представляет картину болезни...» [7, с. 534-535]. Эти высказывания Ницше передают не только социально-психологическую типику имеющего определённые исторические рамки декаданса, но и его архетипику, по отношению к которой Платон, во всяком случае в его эстетической теории, находится в столь отчётливой оппозиции, что в этом смысле его сложно причислить к данной культурной тенденции. (Мы здесь не будем специально касаться вопроса о том, в каком смысле Ницше характеризует творчество Платона в контексте декаданса.)

В рассуждениях Платона об искусстве просматривается тенденция, которая близка по своей сути винкельмановско-гегелевским представлениям о классическом идеале, а также тому, что Ницше называл классическим стилем. Винкельман писал: «Единственный путь для нас сделаться великими и, если можно, даже неподражаемыми - это подражание древним...» [8, с. 86]. В качестве величайших примеров такого подражания он приводит творения Микеланджело, Рафаэля, Пуссена. Эти и другие знатоки греческого искусства находили в нём не просто прекрасную натуру, но «...некую идеальную её красоту, которая, как учит нас один древний толкователь Платона, создаётся из образов, набросанных разумом» [8, с. 88]. Сам Рафаэль, между прочим, писал графу Кастильоне следующее: «И я скажу Вам, что для того, чтобы написать красавицу, мне надо видеть много красавиц... Но ввиду недостатка как в хороших судьях, так и в красивых жен- 


\section{Философия и культура 4(100) • 2016}

щинах, я пользуюсь некоторой идеей (Курсив мой. - В.Д.), которая приходит мне на мысль. Имеет ли она в себе какое-либо совершенство искусства, я не знаю, но очень стараюсь его достигнуть» [9, с. 156157]. Винкельман ценил в искусстве именно обобщённую, в этом смысле идеальную красоту, устремлённость к идеально-скульптурным образам, сдержанным и грациозным, в которых искусство и мудрость соединены в единое целое. В противоположность благородной простоте и спокойному величию (именно так характеризовал Винкельман античный художественно-эстетический идеал) античных поз Винкельман говорит о «вульгарном вкусе» современных ему художников: «Их одобрения заслуживает только то, в чём господствуют необычайные, отличающиеся наглой страстностью позы и действия, которые, по их мнению, выполнены остроумно...» [8, с. 109-110]. По сути, искусство, согласно Винкельману, ценно в той мере, в какой оно способно передать в доступной чувствам форме обладающие значительной экзистенциальной и метафизической ценностью идеи. Это не что иное, как пластически-чувственно выраженная ментальная интуиция - идеально-обобщённая, но весьма экспрессивная, - именно так следовало бы понимать Винкельмана, а также Платона, иначе ряд их высказываний могут быть поняты в слишком упрощённом смысле. Как, например, такое высказывание Винкельмана: «Кисть, которой работает художник, следует предварительно пропитать разумом...» [8, с. 133].

Платон констатирует ритм и гармонию как предусловия благости существования. Ритм и гармония, конечно, - нечто формальное, но формальность гармонии, ритма у Платона есть особое бытие сущих. Здесь мы имеем дело с одним из аспектов онтологии красоты: гармония и ритм оказываются тем, что определяет сущее в соответствии с его благом. В этом смысле поистине быть означает быть чем-то определённым, быть в качестве определённого мерой. Итак, to calon (греч. to calon - прекрасное, хорошее, красота, добродетель) оказывается непосредственно связанным с peras (греч. peras - конец, край, предел, граница), красота вытекает из предела как определяющего сущее в соответствии с его мерой, в этом - красота и благость сущего. Это весьма важно для понимания онтологического смысла не только платоновской, но, пожалуй, и всей античной эстетики. В этом контексте становится понятным, что означает «...соответствие между благообразием и ритмичностью, с одной стороны, и уродством и неритмичностью - с другой» [2, с. 167]. В этом и состоит воспитательное значение мусического искусства (музыки, по- эзии, танца): выявить и привить родовую черту благообразия - гармонию и ритм. Именно мусическое искусство всего сильнее затрагивает душу в её единстве с телом и умом: «...ритм и гармония несут с собой благообразие, а оно делает благообразным и человека...» [2, с. 168].

Важной темой в платоновской концепции эстетического воспитания оказывается также взаимообусловленность мусического и гимнастического воспитания. При пренебрежении тем или другим искусством мы имеем две крайности: грубость с одной стороны и изнеженность, точнее мягкость, - с другой. Эти качества, будучи природными, не являются негативными сами по себе, но при правильном воспитании должны стать своего рода энергией для высвобождения собственно добродетельных природных свойств. Так, «...грубость могла бы способствовать природной ярости духа и при правильном воспитании обратилась бы в мужество...» [2, с. 179]. С другой стороны, кротость свойство характеров, склонных к философии, кротость следует поддерживать воспитанием, чтобы она не стала чрезмерной мягкостью. Ярость духа и кротость - природные свойства, которые посредством воспитания должны друг с другом согласовываться, - вот непременный этический идеал, обладающий отчётливым эстетическим качеством: «Очевидно, именно ради этих двух сторон [человеческой природы] какой-то, я бы сказал, бог даровал людям два искусства: мусическое искусство и гимнастику, но не ради души и тела (это разве что между прочим), а ради яростного и философского начал в человеке, чтобы оба они согласовывались друг с другом, то как бы натягиваясь, то расслабляясь, пока не будет достигнуто надлежащее их состояние» [2, с. 180].

Значительная часть Десятой книги «Государства» Платона посвящена критике миметического искусства. Эта тема принципиально важна для понимания платоновской эстетики, поэтому остановимся на ней более подробно. Итак, Платон не допускает в своё идеальное государство подражательные искусства, весьма обстоятельно обосновывая эту свою точку зрения. Думается, что интерес представляет само это обоснование. Платон предлагает иерархическую схему (ставшую уже в некотором смысле классической) творения вещей: вещи как идеи; вещи, созданные мастерами-ремесленниками; так сказать, псевдо-вещи - изображения, копии, мимемы. В «Тимее» Платон говорит: «...поскольку образ не в себе самом носит причину собственного рождения, но неизменно являет собою призрак чего-то иного, ему и должно родиться внутри чего-то иного, как бы прилепившись к 
сущности, или вообще не быть ничем» [10, с. 455]. Творцом в Древней Греции считался ремесленник, а не живописец. Платон в качестве примера говорит об изготовлении кровати и её изображений, которые оказываются всего лишь призрачными её отображениями. Подражательной, конечно же, оказывается живопись, поскольку она продуцирует лишь видимости. Несмотря на то, что искусства плотника, ткача - подражательные, их Платон всё же не называет подражателями. Плотник, как и ткач, - tecton (греч. - плотник, строитель; художник, мастер), а живописец - mimetes (греч. - подражатель, воспроизводитель). Техника плотника и строителя не есть подражание живописца, первые производят то, что содержит в себе изменение, жизнь, встраивается в поток жизни, тогда как второй производит только копии-видимости, всегда тождественные себе, как написанный когда-то текст в определённом смысле есть всегда один и тот же, всегда равен себе. В этом смысле Платон непосредственно связывает живопись с письмом (греч. zoographia - живопись, буквально - «записывание» жизни. То же смысловое сочетание, очевидно, присуще слову «живопись» и в русском языке): «В этом, Федр, дурная особенность письменности, поистине сходной с живописью: её порождения стоят, как живые, а спроси их - они величаво молчат. То же самое и с сочинениями: думаешь, будто они говорят, как разумные существа, но если кто спросит о чем-нибудь из того, что они говорят, желая это усвоить, они всегда отвечают одно и то же» [11, с. 187].

Итак, мимемы, подражания не только есть видимости действительности, а не сама действительность, но к тому же ещё всегда равны себе, они не есть жизнь, но - просто её картина. Подражатели «творят» только лишь подобные картины.

Трагедию, как и живопись, в качестве подражательного искусства Платон помещает на третье место от сущности, поскольку трагические поэты, как полагает Платон, подобно живописцам, не производят ничего подлинного, действительного, т.е. того, что производят ремесленники, законодатели, педагоги. Но вот, пожалуй, главное обвинение, предъявляемое Платоном трагической поэзии: она способна навредить даже благонравным людям, и лишь немногие составляют здесь исключение: «Выслушай и суди сам: мы - даже и лучшие из нас, - слушая, как Гомер или кто иной из творцов трагедий изображает кого-либо из героев охваченным скорбью и произносящим длиннейшую речь, полную сетований, а других заставляет петь и в отчаянии бить себя в грудь, испытываем, как тебе известно, удовольствие и, поддаваясь этому впечат- лению, следим за переживаниями героя, страдая с ним вместе и принимая всё это всерьёз. Мы хвалим и считаем хорошим того поэта, который настроит нас по возможности именно так» [2, с. 403]. Но ведь в своей не воображаемой, а действительной жизни, как говорит Платон, достойный человек, даже в несчастье, старается избегать всего этого - сетований, стенаний, плаксивости, во всяком случае, этот человек не считает это достойным. Тем не менее, подобные зрелища в искусстве не вызывают отвращения, а доставляют удовольствие.

Этот аргумент Платона не есть достояние только лишь древности. Так, Ж.-Ж. Руссо, как и Платон, внимательно относившийся к проблеме соотношения искусства и этоса, полагал, что происхождение искусства - в определённом смысле следствие человеческих пороков и страстей, которые искусство постоянно подогревает. Руссо писал: «Как вы думаете, что изображают выставленные на всеобщее обозрение в наших садах статуи, а в галереях картины - эти лучшие произведения искусства? Защитников отечества или, быть может, ещё более великих людей - тех, кто обогатил его своими добродетелями? О нет, это образы всех заблуждений сердца и ума, старательно извлечённые из древней мифологии и слишком рано предложенные вниманию наших детей, - без сомнения, чтобы перед глазами у них были собраны образцы дурных поступков, ещё прежде, чем они выучатся читать» $[12$, с. 60]. В «Письме к Д`Аламберу о зрелищах» Руссо высказывает мысли, чуть ли не цитируя известные фрагменты «Государства» Платона. (Впрочем, в одной из сносок Руссо непосредственно цитирует «Государство».) Руссо говорит, что зрелища не могут быть полезными для общества, поскольку в театре люди забывают свою реальную жизнь, чтобы увлечься выдумками, оплакивая и осмеивая воображаемых героев. Эффект зрелища не польза, а удовольствие. Руссо возражает против положения аристотелевской «Поэтики» (а в лице Аристотеля, как известно, античная трагедия, по существу не принимаемая Платоном в идеальное государство, нашла своего защитника и теоретика), согласно которому во время театрального действия происходит очищение аффектов посредством их возбуждения: «...надо бы ещё проверить, - пишет Руссо, - не перерождается ли страсть, при чрезмерном её раздражении, в порок. Я знаю: поэтика приписывает театру как раз обратное, т.е. очищение страстей через их возбуждение; но я чтото плохо это понимаю. Выходит, что прежде чем стать сдержанным и благоразумным, надо сперва быть и неистовым и сумасшедшим?» [13, с. 79]. Никакой нравственной ценности не имеют, согласно 


\section{Философия и культура 4(100) • 2016}

Руссо, слёзы всех этих «театральных плакальщиц»: «Говорят, будто трагедия ведёт через страх к состраданию. Допустим, - но что это за сострадание? Преходящее пустое волнение, длящееся не дольше вызвавшей его иллюзии; остаток естественного чувства, вскоре заглушённый страстями; бесплодная жалость, довольствующаяся лёгкой данью в виде нескольких слезинок и ни разу ещё не породившая ни одного гуманного поступка» $[13$, с. 83]. Впрочем, Руссо, как и Платон, не отрицает искусство как таковое, но подвергает критике определённые его тенденции, направления - именно те, которые способствуют появлению всевозможных аффектов, нарушающих разумную гармонию человеческой души, - аффектов, в свете которых зло становится привлекательным, эстетизируется. Эти «неодолимые чары», о которых говорит Руссо, - не что иное, как «сладостная Муза», против чар которой Платон приводит свои аргументы. Изгнание Платоном подражательных поэтов и живописцев из идеального государства можно в определённом смысле сопоставить с изгнанием Руссо зрелищ и даже части изобразительных искусств из топоса естественного общества.

От нашего внимания не должна ускользнуть своего рода правота Платона в этом вопросе: искусство, поскольку оно нас зачаровывает, подчинено исключительно принципу удовольствия. В этой связи следует упомянуть рассуждения 3. Фрейда о поэтической фантазии, в которых говорится о неприглядной с точки зрения общественной морали материи поэтических произведений. Согласно Фрейду, материалом этих фантазий и произведений могут быть как инфантильные сексуальные переживания, так и мучительные переживания, которые, однако, доставляют удовольствие. Если перевести рассуждения Фрейда в режим платоновской мысли, то получится, что человек в известном смысле регрессирует в рамках искусства к влечениям, усиленно подавляемым культурой, и испытывает при этом интенсивные удовольствия - сублимация ведь невозможна без попятного движения десублимации. (Здесь нет никакого противоречия приведённому выше примеру из Руссо, поскольку «естественный» человек у Руссо весьма опосредован культурой уразумения и пестования добродетелей сердца.) В этом смысле аргументы Платона против подражательного искусства, при соответствующей их интерпретации, учитывающей также всю палитру античного мимесиса, могли бы приобрести новые оттенки.

Однако же определённую часть поэзии Платон принимает в своё идеальное государство, но только ту поэзию, которая в этом государстве полезна,
- полезна в высшем смысле. Критерием для Платона здесь является только лишь благо, а не само поэтическое начало как таковое. Итак, в той мере, в какой поэзия может способствовать идеальному, справедливому государству, в той мере она должна быть принята в него, но ни в коем случае не за то, что она - поэзия, как и любовь, если она бесполезна, не должна быть принята в душу и подлежит изгнанию. По сути, всё, что допускает Платон из поэзии, - это сочинение и исполнение гимнов богам, а также произведений, в которых воздаётся хвала добродетельным, т.е. ориентированным прежде всего на общественное благо людям. Однако, несмотря на то, что искусство способно обманывать, зачаровывать сознание человека и тем самым заслонять реальность от человеческого взора, - в этом свойстве искусства Платон всё же видит определённую долю полезного. Так, pseydos словесный может быть полезен в смысле трансляции культурно ценных преданий: «Да и в тех преданиях, о которых мы только что говорили, не делаем ли мы ложь полезной, когда как можно более уподобляем её истине, раз уж мы не знаем, как это всё было на самом деле в древности?» [2, с. 147].

Итак, правильность мусического искусства, согласно Платону, вовсе не тождественна степени удовольствия, получаемого от него, - удовольствие от эстезиса может вступать в противоречие с этосом. Очевидно, Платон отдаёт решительное предпочтение этике, а не эстетике, а эстетику принимает в той мере, в какой она не противоречит этике. Сам же Платон не раз говорит, что поэтическое воображение может вовсе не согласовываться с добродетелью, но при этом искусство не перестаёт быть искусством, не перестаёт очаровывать людей. Очевидно, что цель рассуждений Платона - выявить пользу, приносимую искусством, а значит, определить дозволенные в контексте блага рамки последнего. Но ведь искусство доставляет удовольствие и не существует иначе в качестве именно искусства. Однако принципиально важным оказывается разграничение удовольствия, связанного с приятностью, с одной стороны, и правильности и пользы - с другой. Причём, две последних позиции, по сути, не связаны с первой: «Точно так же и в учении присутствует связанное с приятностью удовольствие, а истина довершает правильность, пользу, благо и красоту» [14, с. 117]. Правильностью в изобразительных искусствах, в контексте данных рассуждений Платона, является своего рода равенство, мера сходства произведения с оригиналом. Это сходство, конечно, может доставлять вдобавок удовольствие, однако правильность, доставляющая удовольствие, обуслов- 
лена не удовольствием, а «...равенством воспроизведения и подлинника в отношении величины и качества» $[14$, с. 117]. В своей критике определённых тенденций миметического искусства Платон в данном случае, скорее всего, имел в виду существовавшую в то время модную школу иллюзионистской живописи, представителями которой были Аполлодор, Зевксис, Паррасий, использовавшие в своих произведениях светотень, перспективу и другие живописные средства, позволявшие создать лишь иллюзию сходства. Эти «живописцы тени», как их называли, пренебрегали, согласно Платону, «сущностью», выражавшейся в структуре изображаемого объекта, - его мерой, соотношением частей и целого и т.д. - всем тем, чего придерживался Полигнот и чего не могли не придерживаться также и мастера-ремесленники, а не подражатели. В «Софисте» Платон говорит о двух видах искусства подражания: искусстве творить образы и искусстве творить призрачные подобия. Образ-подобие не есть призрак. Искусство творить образы «...состоит преимущественно в том, что кто-либо соответственно с длиною, шириною и глубиною образца, придавая затем ещё всему подходящую окраску, создаёт подражательное произведение» $[15$, с. 299-300]. Но вот если художник изображает нечто большое, скажем, создаёт большие статуи, при этом искажая их в целях приспособления к определённому углу восприятия, - что было распространённой во времена Платона манерой, - тогда художник, согласно Платону, создаёт не образы-копии, а призрачные подобия. Если встать на точку зрения эффектов, «красоты», очарования, тогда, действительно, статуи больших размеров, созданные в соответствии с рекомендациями Платона, были бы лишены определённого эффекта при их восприятии. Ведь тогда художникам-скульпторам пришлось бы ориентироваться не на эффекты, а на объективные соразмерности. Фактически Платон в данном случае призывает к точному копированию оригинала, однако, при условии знания самого этого оригинала. (Поскольку богов копировать невозможно, в случае изваяний богов речь, очевидно, должна была идти о должных пропорциях человеческого тела, а также о должном выражении патетики.)

Ещё в «Гиппии Большем», а затем в «Пире» и «Государстве» Платон ставил под сомнение расхожие представления о красоте. И в данном случае речь идёт о том, что удовольствие производится правильностью и присоединяется к ней. Мерилом такого искусства, очевидно, является не удовольствие как таковое, а «от-чего» удовольствия, т.е. удовольствие в горизонте блага. Впрочем, Пла- тон выделяет в самостоятельную сферу и тот род деятельности и созерцания, мерилом которого является только удовольствие: «Следовательно, удовольствие служит правильным мерилом только в таких вещах, которые хотя и не несут с собой пользы, истины и подобия, однако, с другой стороны, не доставляют и никакого вреда, но творятся исключительно ради того, что в других случаях является лишь сопутствующим, т.е. ради приятности, которую великолепно можно назвать удовольствием, если с ней не связаны вышеупомянутые свойства» [14, с. 117-118].

Итак, мерилом подражания, за исключением только что вышеозначенного, не может быть удовольствие как таковое, ведь равенство, соразмерность являются таковыми не потому, что они доставляют удовольствие, мерой здесь является, по существу, истина. Но истина не может быть бесполезной, ибо касается не просто сущего, но и устройства в нём человеческого существования, соразмерности последнего с сущим. Забава, доставляющая удовольствие, конечно, может быть безвредной, не принося и пользы в смысле этой соразмерности. Но не такой забавой в глазах Платона должно быть мусическое искусство. Во всяком случае, не всякого рода мусическое искусство может быть принято в идеальное государство. Мерилом мусического искусства не является удовольствие: «Надо исследовать лишь тот род мусического искусства, который, воспроизводя прекрасное, обладает с ним сходством... Поэтому люди ищущие самую прекрасную песнь, должны разыскивать, как кажется, не ту Музу, что приятна, но ту, которая правильна. А правильность подражания заключается, как мы сказали, в соблюдении величины и качества подлинника» [14, с. 118]. Правильность - непременное условие красоты, но в целях соблюдения правильности поэты, художники должны следовать не своим случайным желаниям, но - Музам, старательно обучаясь ритму, гармонии, вслушиваясь не в «напевы» сиюминутных человеческих страстей, а в универсальный строй гармонии. Польза же искусства заключена в его способности гармонизировать человека и социум с космосом, с его ритмами.

\section{Красота геометрических структур и сфера чистых удовольствий}

Эта тема с большой полнотой и насыщенным аналитизмом обсуждается Платоном в диалоге «Филеб». (Основой изложения данной темы является здесь феноменологическая интерпретация «Филеба» Гансом Георгом Гадамером [17].) Центральной темой диалога является обнаружение чистых 


\section{Философия и культура 4(100) • 2016}

удовольствий и соответствующих им феноменов в контексте эйдосов красоты и блага. (Эйдос блага в данном контексте следует уточнить: по отношению к бытию человека благо следовало бы понимать не как то, чем человек обладает или может обладать, а как состояние души или способ бытия человека [см.: 17]. Платон стремится уяснить характер благости внутри самих удовольствий. Этот ход мыслей приведёт Платона к эстетической проблематике, соотнесённой с основами человеческого существования. Позиция Платона состоит в том, что удовольствие как таковое, т.е. в его бытии удовольствием (без усмотрения «от-чего» удовольствия) невозможно назвать благим: «В самом деле, по твоим словам, всё приятное - это благо. Никто не станет, конечно, оспаривать, что приятное приятно; однако, несмотря на то, что многое из приятного, как мы сказали, дурно, а многое, наоборот, хорошо, ты называешь все удовольствия благом, хотя и готов согласиться с тем, что они несходны друг с другом...» [16, с.9]. Ключевым моментом в дальнейшем ходе рассуждений Платона является совместное рассмотрение удовольствия и страдания: «...страдание и удовольствие возникают по природе своей совместно, в смешанном роде» [16, c.31]. Любое телесное удовольствие, как, например, от еды или питья, возможно только благодаря преодолению предшествующего страдания - голода или жажды. Таким образом, телесное удовольствие, будучи смешанным со страданием, не является чистым удовольствием - удовольствием, максимально соответствующим своему эйдосу. Но наряду с телесными удовольствиями может быть выделен и самостоятельный род душевных удовольствий: «Допусти теперь, что в самой душе существует ожидание этих состояний, причём предвкушение приятного доставляет удовольствие и бодрит, а ожидание горестей вселяет страх и страдание» $[16$, с. 33]. Таким образом, когда ожидание удовольствия само по себе является удовольствием, оно относится уже к роду душевных удовольствий. У таких - душевных - удовольствий есть существенное преимущество перед телесными: душевные удовольствия могут встречаться в чистом виде - без предшествующего им страдания (неудовольствия). В частности, ожидание удовольствия вовсе не предполагает с необходимостью ожидания неудовольствия или телесного ощущения неудовольствия.

Анализируя различные виды удовольствия, Платон показывает, что многие удовольствия лишь кажутся таковыми, т.е. истинными удовольствиями, не являясь таковыми в своём бытии. Теперь же задача Платона - выявить феномен ис- тинного удовольствия, - удовольствия, не связанного с страданием, т.е. чистого. Возможность таких чистых, несмешанных удовольствий Платон объясняет следующим образом. С фактической точки зрения, радости, доставляемой удовольствием, необходимо предшествует некое отсутствие, опустошённость, требующие наполнения, а значит - некое страдание. Но это страдание может оставаться потенциальным и не стать актуальным, поскольку опустошённость не переживается как страдание, а значит, не переживается и соответствие страдания от опустошённости радости от наполнения. Таким образом, отсутствие, опустошённость не переживаются как страдание, однако же наполнение, т.е. соприкосновение с объектом удовольствия, доставляет радость: «Это удовольствия, вызываемые красивыми, как говорят, красками, очертаниями, многими запахами, звуками и всем тем, в чём недостаток незаметен и не связан со страданием, а восполнение заметно и приятно» $[16$, с. 58]. Грубовато, но лаконично и определённо заявляет Платон о своих приоритетах в отношении красоты: «Под красотой очертаний я пытаюсь теперь понимать не то, что хочет понимать под ней большинство, т.е. красоту живых существ или картин; нет, я имею в виду прямое и круглое, в том числе, значит, поверхности и тела, рождающиеся под токарным резцом и построяемые с помощью линеек и угломеров, если ты меня понимаешь. В самом деле, я называю это прекрасным не по отношению к чемулибо, как это можно сказать о других вещах, но вечно прекрасным самим по себе, по своей природе и возбуждающим некие особые, свойственные только ему удовольствия, не имеющие ничего общего с удовольствием от щекотания. Есть и цвета, носящие тот же самый характер» [16, с. 58-59]. Форма, выявляющая некое жизненное содержание, будь она даже просто нарисованной или же, скажем, существуй она лишь в ментальном образе, - если пытаться понять Платона, - несовместима с чистым удовольствием. Ведь удовольствие, получаемое от созерцания предметов, обладающих такими формами, является оборотной стороной страдания, поскольку это удовольствие, так или иначе, сополагается с жизненными инстинктами, вожделениями и устремлениями. Чистые же формы (в пределе геометрические формы, а также цвета и, возможно, звуки как таковые) красивы и доставляют чистую радость не потому, что они видятся нами из нашего жизненного горизонта, но - сами по себе, ведь они, как таковые, не входят в сферу вожделения, влечения и не характеризуют наше бытие как бытие именно живых - т.е., страдающих и вожделеющих существ. Что ожидать человеку и к чему стремить- 
ся, если в поле его созерцания - линии, окружности, геометрические плоскости и тела? Ведь чувству удовольствия, которое они, возможно, вызовут, не предшествует с необходимостью вожделение, страдание, а значит, - неудовольствие, когда их ещё нет. Да и их исчезновение, в силу того что они не находятся в сфере устремлений, не сопровождается с необходимостью неудовольствием, печалью, сожалением. Сущее, раскрытое в таком чистом удовольствии, «...не нужно ожидать или предполагать как радостное... удовольствие даётся вместе с этим сущим и в его открытости. Следовательно, такая радость от чего-то происходящего (От простого присутствия чего-то, без предварительной (когда оно ещё не появилось) или последующей (когда оно уже исчезло) устремлённости к нему. (Прим. моё. - В.Д.)) и есть искомая «истинная» радость. В ней достигает высшей точки возможность той истинности, которой вообще может обладать аффект. Ведь Платон рассматривал аффект в общем как способ раскрытия мира» [17, с. 207].

Критика Платоном искусства, о которой шла речь выше, а также критика обыденных, психологизированных и сентиментализированных представлений о красоте, о которой шла речь только что, как оказалось, не просто имеет свои законные рациональные основания, но даже своего рода практическое осуществление в сфере художественной. Это, прежде всего, искусство минимализма середины XX в. (США) и абстрактная живопись. Цвет, освобождённый от конкретных форм действительности, цвет как самостоятельная эстетическая ценность, а также прямые и ломаные линии, плоскости, геометрические формы, - всё это стало предметом абстрактного искусства, во всём этом улавливалась красота, существенным образом отличная от красоты живых существ, органических форм. Лучизм М. Ларионова, супрематизм К. Малевича, абстрактный экспрессионизм В. Кандинского, неопластицизм П. Мондриана, - во всех этих направлениях абстрактного искусства была одна общая для них ключевая тенденция: выразить красоту космическую, божественную, надвременную, ясную, духовную, в отличие от случайной, неопределённой, капризной земной красоты.

Известные практики и теоретики минимализма 60-х гг. XX в. Р. Моррис и Д. Джадд размышляли о том, каким образом можно создать визуальный объект, исключающий всякий пространственный иллюзионизм. Джадд считал, что любая живопись, в том числе модернистская, создаёт пространственную иллюзию: «Всё, что находится на поверхности, имеет за собой пространство. Два цвета на одной поверхности почти всегда находятся на разной глубине» [цит. по: 18, c. 29]. Таким лишённым пространственной иллюзии визуальным объектом является в минимализме трёхмерный пространственный объект геометрической формы. Эти объекты предохранены «...от перемен настроения, от перемен смысла, от нюансов и переливов, создающих ауру, от тревожных странностей всего того, что способно преображаться или попросту свидетельствует о работе времени» [18, с. 34-35]. Классическим примером здесь может служить параллелепипед из фанеры Дональда Джадда - простой видимый объект геометрической формы, освобождённый от всех модальностей образного языка и даже от всего антропоморфного. Как подчёркивает Диди-Юберман, у подобных объектов нет ауры - нет диалектики далёкого-близкого, скрытого-проявленного, поэтому нет никакой выразительности.

Из вышеизложенного, в принципе, понятно, каким образом даже предельные минималистские объекты, - такие, например, как «Параллелепипед» Джадда, не теряя ничего в своей минимальности, могут быть если не предметом искусства, включающего антропологические механизмы, то, во всяком случае, - если сказать об этом в контексте платоновской мысли, - предметом непосредственно соотнесённого с благом и дающего чистую радость эстетического созерцания: для этого должен включиться механизм «чистого удовольствия», подробнейшим образом проанализированный Платоном в «Филебе».

\section{Совместное существование феноменов эротического устремления к красоте и благоговения в теологической перспективе}

Когда Платон в «Федре» говорит об эротическом восхождении к божественной и чистой красоте, кажется, что речь у него идёт о какой-либо из ступеней посвящения в Элевсинские мистерии. Такое предположение не столь произвольно, как могло бы показаться. Действительно, в текстах Платона мы находим небольшие отрывки, касающиеся мистерий, которые, как известно, представляли собой театрализованные зрелища, имеющие религиозно-мистический и очистительный смысл. «Сияющую красоту можно было видеть тогда, когда мы вместе со счастливым сонмом видели блаженное зрелище, одни - следуя за Зевсом, а другие - за кем-нибудь другим из богов, и приобщались к таинствам, которые можно по праву назвать самыми блаженными и которые мы совершали, будучи сами ещё непорочными и не испытавшими зла, ожидавшего нас впоследствии. Допущенные 


\section{Философия и культура 4(100) • 2016}

к видениям непорочным, простым, неколебимым и счастливым, мы созерцали их в свете чистом, чистые сами и ещё не отмеченные, словно надгробием, той оболочкой, которую мы теперь называем телом и которую не можем сбросить, как улитка - свой домик» [11, с. 159]. Припоминание этих зрелищ, данное, согласно Платону, немногим людям, основа того неистовства, той мании, которая, если посмотреть на неё с точки зрения эмпирической, могла бы показаться простым безумием и экзальтацией: «А это есть припоминание того, что некогда видела наша душа, когда она сопутствовала богу, свысока глядела на то, что мы теперь называем бытием, и поднималась до подлинного бытия» $[11$, с. 158]. Состояние эраста - эротический восторг - Платон называет наилучшей манией из всех видов маний. Согласно Платону, неистовство этого рода возникает вследствие пробуждения памяти о неземной, истинной красоте при взгляде на красоту здешнюю. Именно земной красотой влечётся душа человека к красоте духовной и божественной. В этом хитросплетении эротических и духовных устремлений проницательный взгляд эраста прозревает в облике прекрасного юноши черты божества: «Между тем человек, только что посвящённый в таинства, много созерцавший тогда всё, что там было, при виде божественного лица, хорошо воспроизводящего [ту] красоту или некую идею тела (курсив мой. - В.Д.), сперва испытывает трепет, на него находит какой-то страх, вроде как было с ним и тогда; затем он смотрит на него с благоговением, как на бога, и, если бы не боялся прослыть совсем неистовым, он стал бы совершать жертвоприношения своему любимцу, словно кумиру или богу. А стоит тому на него взглянуть, как он сразу меняется, он как в лихорадке, его бросает в пот и в необычный жар» $[11$, с. 160]. Стоит внимательно вчитаться в эти и другие строки, являющиеся блестящим описанием феномена эротического влечения и сосуществующих с ним феноменов страха, удовольствия и благоговения, доходящего до восторга. Это необычное, экстатичное состояние страдания, страха и удовольствия - состояние, стремящееся сосредоточиться на созерцании божества, - это состояние, сравниваемое Платоном с зудом и раздражением в деснах, когда прорезываются зубы, освобождает душу от привязанностей к земному, рождая крылья. Но не следует забывать, что речь идёт о языческой философии, языческой мистике и религии: «Странность такого смешения её (Душу влюбленного. (Прим. моё. - В.Д.)) терзает, в недоумении она неистовствует, и от исступления не может она ни спать ночью, ни днём оставаться на одном месте. В тоске бежит она туда, где думает увидеть обладателя красоты. При виде его влечение разливается по ней, и то, что было ранее заперто, раскрывается: для души это передышка, когда прекращаются уколы и муки, в это время вкушает она сладчайшее удовольствие... Презрев все обычаи и приличия, соблюдением которых щеголяла прежде, она готова рабски служить своему желанному и валяться где попало, лишь бы поближе к нему - ведь помимо благоговения перед обладателем красоты она обрела в нём единственного исцелителя величайших страданий. Состояние, о котором у меня речь, прекрасный мой мальчик, люди зовут Эротом...» [11, с. 160-161].

Нельзя не заметить того обстоятельства, что Платон говорит об Эроте и эротическом опыте в связи с опытом мистического созерцания божества посредством облика красивого юноши, который становится для эраста чем-то вроде эйдолона, - изваяния, в котором эраст как бы отслеживает природу своего бога, обретая вновь причастность ему и стремясь сделать причастным своего возлюбленного. Впрочем, такой опыт вовсе не исчерпывает всей платонической мистики, а характерен для той её части, в которой созерцание божества и единение с божеством происходят в непосредственном единстве с эстетическим и эротическим опытом. Вершиной же религиозно-мистического созерцания в платонизме является состояние, в котором угасают аффекты, а человеческое существо присутствует лишь в той мере, в какой созерцает идеи. Не случайно А. Лосев сближает в этом смысле платоническую и византийскую христианскую мистику: «Мистикплатоник, как и византийский монах (ведь оба они, по преимуществу, греки), на высоте умной молитвы сидят спокойно, погрузившись в себя, причём плоть как бы перестаёт действовать в них, и ничто не шелохнется ни в них, ни вокруг них (для их сознания). Подвижник отсутствует сам для себя; он существует только для славы Божией» [6, с. 884].

Тема эстетики и зротики в связи с теологией актуальна, конечно, отнюдь не только в рамках язычества как такового (в рамках исторического язычества), но также и в рамках христианского опыта. Пожалуй, одним из самых ярких в этом смысле текстов является «Исповедь» бл. Августина, оправдывавшего ценность земной красоты в той мере, в какой этой красотой следует пользоваться как средством для того, чтобы наслаждаться красотой духовной. Но есть в католической литературе тексты, в которых религиозно-мистический экстаз столь непосредственно соединён с опытом эстетическим и эротическим, что сама собой напрашивается аналогия с описаниями в платоновском «Федре». Речь идёт об одном из по- 
добных текстов - об «Откровении бл. Анджелы», в котором религиозно-мистический экстаз имеет, на наш взгляд, нечто общее с описаниями в платоновском «Федре». (Точка зрения, возможно, не бесспорная, однако, опирающаяся на ряд очевидных сходств.) Приведём комментарии Лосева и соответствующие цитаты: «Святая находится в сладкой истоме, не может найти себе места от любовных томлений. А Возлюбленный всё является и является и всё больше и больше разжигает её тело, её сердце, её кровь. Крест Христов представляется ей брачным ложем. Она сама через это входит в Бога: «И виделось мне, что нахожусь я в середине Троицы...». Она просит Христа показать ей хоть одну часть тела, распятого на кресте; и вот Он показывает ей... шею. «И тогда явил Он мне Свою шею и руки. Тотчас же прежняя печаль моя превратилась в такую радость и столь отличную от других радостей, что ничего и не видела и не чувствовала, кроме этого. Красота же шеи Его была такова, что невыразимо это. И тогда разумела я, что красота эта исходит от Божественности Его. Он же не являл мне ничего, кроме шеи этой, прекраснейшей и сладчайшей. И не умею сравнить этой красоты с чемнибудь, ни с каким-нибудь существующим в мире цветом, а только со светом тела Христова, которое вижу я иногда, когда возносят его»... В довершение всего Христос обнимает Анджелу рукою, которая пригвождена была ко кресту, а она, вся исходя от томления, муки и счастья, говорит: «Иногда от теснейшего этого объятия кажется душе, что входит она в бок Христов. И ту радость, которую приемлет она там, и озарение рассказать невозможно. Ведь так они велики, что иногда не могла я стоять на ногах, но лежала и отымался у меня язык... И лежала я, и отнялись у меня язык и члены тела» [цит. по: 6, c. 884-885]. Присоединимся здесь к мнению Лосева: «Это, конечно, не молитва и не общение с Богом. Это - очень сильные галлюцинации на почве истерии, т.е. прелесть. [...]... весь этот бедлам эротомании, бесовской гордости и сатанизма - можно, конечно, только анафематствовать...» [6, с. 885].

Не стоит, однако, забывать, что опыт Платона - языческий, и вся эротическая сфера любви к юношам открыто сублимируется у него в религиозномистическое созерцание. Впрочем, эротика - земная и возвышенная - выглядит у Платона гораздо более убедительней, более человечней, что ли, чем в приведённом выше тексте католической мистики. Однако, это всего лишь наше субъективное мнение. Но совершенно очевидно, что было бы неправильным не видеть в учении Платона о красоте, об искусстве, о «правильной» любви к юношам тех, в конечном итоге, возвышенных устремлений, которые пронизывают всю его философию. Как и вся философия Платона, его эстетика - поиск блага, его оснований в человеческой жизни, открытие высочайших возможностей человеческой экзистенции.

\section{Список литературы:}

1. Плотин. Эннеады: 5; 12; 33 / Пер. с древнегреч. и англ. Киев, 1995.

2. Платон. Государство: Кн. 2: 378de; 382cd. Кн. 3: 387bc; 390c; 400c; 401d; 410d; 411e - 412a. Кн. 10: 605cd; 606d / Пер. с древнегреч. А.Н. Егунова // Платон. Собр. соч. в 4 т. Т. 3. М., 1994.

3. Шеллинг Ф.В.Й. Философия откровения: в 2 т. Т. 1 / Пер. с нем. А.Л. Пестова. СПб., 2000.

4. Платон. Письмо Седьмое: 341c / Пер. с древнегреч. С.П. Кондратьева // Платон. Собр. соч.: в 4 т. Т. 4. М., 1994.

5. $\quad$ Гомер. Илиада (п. 14; 294) / Пер. с древнегреч. Н. Гнедича. М., 1985.

6. Лосев А.Ф. Очерки античного символизма и мифологии. М., 1993.

7. Ницше Ф. Казус Вагнер. Проблема музыканта / Пер. с нем. Н. Полилова // Ницше Ф. Соч.: в 2 т. Т. 2. М., 1990.

8. Винкельман И.И. Мысли по поводу подражания греческим произведениям в живописи и скульптуре / Пер. с нем. А.А. Алявдиной // Винкельман И.И. Избранные произведения и письма. М.-Л., 1935.

9. Рафаэль. Письмо графу Бальдассаре Кастильоне от 1514 г. / Пер. с ит. А.И. Аристовой // Мастера искусств об искусстве: в 7 т. Т. 2. М., 1966.

10. Платон. Тимей: 52c / Пер. с древнегреч. С.С. Аверинцева // Платон. Собр. соч.: в 4 т. Т. 3. М., 1994.

11. Платон. Федр: 249c; 250bc; 251ab; 251d-252b; 275d / Пер. с древнегреч. А.Н. Егунова // Платон. Собр. соч.: в 4 т. Т. 2. M., 1993.

12. Руссо Ж.-Ж. Рассуждение: Способствовало ли возрождение наук и искусств улучшению нравов? / Пер. с фр. Н.И. Кареева // Руссо Ж.-Ж. Избр. соч.: в 3 т. Т. 1. М., 1961.

13. Руссо Ж.-Ж. Письмо к д' Аламберу о зрелищах // Руссо Ж.-Ж. Трактаты об искусстве. URL: http://www.marsexx.ru/ lit/russo-traktaty--ob-iskusstve.html\#787.

14. Платон. Законы: Кн. 2: 667c; 667d; 667e; 668b / Пер. с древнегреч. А.Н. Егунова // Платон. Собр. соч.: в 4 т. Т. 4. М., 1994.

15. Платон. Софист: 235de / Пер. с древнегреч. С.А. Ананьина // Платон. Собр. соч.: в 4 т. Т. 2. М., 1993.

16. Платон. Филеб: 13ab; 31c; 32bc; 51b; 51cd / Пер. с древнегреч. Н.В. Самсонова // Платон. Собр. соч. в 4 т. Т. 3. М., 1994.

17. Гадамер Г.-Г. Диалектическая этика Платона (Феноменологическая интерпретация «Филеба») / Пер. с нем. О.А. Коваль. СПб., 2000.

18. Диди-Юберман Ж. То, что мы видим, то, что смотрит на нас / Пер. с фр. А. Шестакова. СПб., 2001. 


\section{Философия и культура 4(100) • 2016}

\section{References (transliterated):}

1. Plotin. Enneady: 5; 12; 33 / Perevody s drevnegrech. i angl. Kiev, 1995.

2. Platon. Gosudarstvo: Kn. 2: 378de; 382cd. Kn. 3: 387bc; 390c; 400c; 401d; 410d; 411e - 412a. Kn. 10: 605cd; 606d / Per. s drevnegrech. A.N. Egunova // Platon. Sobr. soch.: v 4 t. T. 3. M., 1994.

3. Shelling F.V.I. Filosofiya otkroveniya: v 2 t. T. 1 / Per. s nem. A.L. Pestova. SPb., 2000.

4. Platon. Pis'mo Sed'moe: 341c // Platon. Sobr. soch.: v 4 t. T. 4 / Per. s drevnegrech. S.P. Kondrat'eva. M., 1994.

5. Gomer. Iliada (p. 14; 294) / Per. s drevnegrech. N. Gnedicha. M., 1985.

6. Losev A.F. Ocherki antichnogo simvolizma i mifologii. M., 1993.

7. Nitsshe F. Kazus Vagner. Problema muzykanta / Per. s nem. N. Polilova // Nitsshe F. Soch.: v 2 t. T. 2. M., 1990.

8. Vinkel'man I.I. Mysli po povodu podrazhaniya grecheskim proizvedeniyam v zhivopisi i skul'pture / Per. s nem. A.A. Alyavdinoi // Iogann - Ioakhim Vinkel'man. Izbrannye proizvedeniya i pis'ma. M.-L., 1935.

9. Rafael'. Pis'mo grafu Bal'dassare Kastil'one ot 1514 g. / Per. s it. A.I. Aristovoi // Mastera iskusstv ob iskusstve: v 7 t. T. 2. M., 1966.

10. Platon. Timei: 52c // Platon. Sobr. soch.: v 4 t. T. 3 / Per. s drevnegrech. S.S. Averintseva. M., 1994.

11. Platon. Fedr: 249c; 250bc; 251ab; 251d-252b; 275d / Per. s drevnegrech. A.N. Egunova // Platon. Sobr. soch.: v 4 t. T. 2. M., 1993.

12. Russo Zh.-Zh. Rassuzhdenie: Sposobstvovalo li vozrozhdenie nauk i iskusstv uluchsheniyu nravov? / Per. s fr. N.I. Kareeva // Russo Zh.-Zh. Izbr. soch.: v 3 t. T. 1. M., 1961.

13. Russo Zh.-Zh. Pis'mo k d' Alamberu o zrelishchakh // Russo Zh.-Zh. Traktaty ob iskusstve. URL: http://www.marsexx.ru/lit/ russo-traktaty--ob-iskusstve.html\#787.

14. Platon. Zakony: Kn. 2: 667c; 667d; 667e; 668b / Per. s drevnegrech. A.N. Egunova // Platon. Sobr. soch.: v 4 t. T. 4 . M., 1994.

15. Platon. Sofist: 235de / Per. s drevnegrech. S.A. Anan'ina // Platon. Sobr. soch.: v 4 t. T. 2. M., 1993.

16. Platon. Fileb: 13ab; 31c; 32bc; 51b; 51cd / Per. s drevnegrech. N.V. Samsonova // Platon. Sobr. soch.: v 4 t. T. 3. M., 1994.

17. Gadamer G.-G. Dialekticheskaya etika Platona (Fenomenologicheskaya interpretatsiya «Fileba») / Per. s nem. O.A. Koval'. $\mathrm{SPb}, 2000$.

18. Didi-Yuberman Zh. To, chto my vidim, to, chto smotrit na nas / Per. s fr. A. Shestakova. SPb., 2001. 